\title{
APPLICATIONS OF NANOTECHNOLOGY WITH HYBRID PHOTOVOLTAICITHERMAL SYSTEMS: A REVIEW
}

\section{Mohammed Alktranee}

University of Miskolc, Faculty of Mechanical Engineering and Informatics, Department of Fluid and Hea Engineering, Miskolc, Hungary

Southern Technical University, Technical Institute of Basra, Mechanical department, Basrah, Iraq

\section{Péter Bencs}

University of Miskolc, Faculty of Mechanical Engineering and Informatics, Department of Fluid and Hea Engineering, Miskolc, Hungary
DOAJ

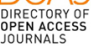

Crossref

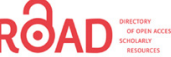

KOBSON

Key words: nanofluid, hybrid PV/T system, thermophysical properties, efficiencies

Cite article:

Mohammed, A., \& Péter, B. [2021]. Applications of nanotechnology with hybrid photovoltaic/thermal systems: a review. Journal of Applied Engineering Science, 19(2) 292 - 306. DOI:10.5937/jaes028760 


\title{
APPLICATIONS OF NANOTECHNOLOGY WITH HYBRID PHOTOVOLTAIC/THERMAL SYSTEMS: A REVIEW
}

\author{
Mohammed Alktranee ${ }^{1,2 *}$, Péter Bencs ${ }^{1}$ \\ ${ }^{1}$ University of Miskolc, Faculty of Mechanical Engineering and Informatics, \\ Department of Fluid and Hea Engineering, Miskolc, Hungary \\ ${ }^{2}$ Southern Technical University, Technical Institute of Basra, Mechanical department, Basrah, Iraq
}

This paper appears potential of use nanofluids as a working fluid with the photovoltaic/thermal (PV/T) systems as an alternative of the conventional liquids in improves the efficiency of the hybrid PV/T system. The review highlights the impact of some parameters (base fluid, volume fraction, the concentration of nanoparticles, surfactants, shape, and size of nanoparticles) on nanofluids' thermophysical properties and their effect on the PV/T system's efficiencies. Hence, it discusses the PV/T behavior, which uses different nanofluids based on previous experimental, analytical, and numerical studies. The review concluded that using nanofluid as a cooling fluid or spectral filter contributes by enhancing the performance and increasing the PV/T system's efficiency. Thus, each type of nanofluids has certain features that contribute to removing the PV cells' excess heat by cooling it, contributing to its work's stability, and increasing its productivity. Nanofluids thermophysical properties play an intrinsic role by enhancing nanofluids' performance, thus positively reflecting on the PV/T system's performance. Despite the variation in the values of thermal and electrical efficiency, Most of the studies that used nanofluids have achieved encouraging results that appeared by improving the performance of PV/T systems.

Key words: nanofluid, hybrid PV/T system, thermophysical properties, efficiencies

\section{INTRODUCTION}

Increased energy demand with greater reliance on conventional energy sources raises concern about the sustainability of conventional energy sources and the possibility of meeting the increase of global energy demand [1]. On the other hand, environmental protection with reducing pollution represents the essential matters for countries and decision-makers [2]. Adopting alternative energy sources, such as solar energy, is an appropriate solution that provides clean energy that contributes to environmental protection, reducing dependence on conventional energy sources. Thus, exploitation of the sunlight and heat that resulted from the sun and converted it to electric and thermal energy [3]. Most of the solar radiation received by photovoltaic (PV) panels not converted to electrical energy. Where $15-20 \%$ converts to electricity by PV panels, and the rest of the solar radiation negatively affects the PV cell's performance as heat [4]. Therefore, raising the PV cell operating temperature will robustly affect the PV panel's performance and the energy produced [5]. Thus overheating leads to full damage of the PV panel [6]. The PV system's low efficiency at rising temperatures is still the main obstacle for adopting sustainable systems [7]. Sustaining the PV panel's operation effective requires maintaining the PV cells' temperature at a suitable range.

Using a cooling technique for the PV panels is a successful method for reducing the PV cells' high temperature and enhancing electrical efficiency [8]. The hybrid $\mathrm{PV} / \mathrm{T}$ system is the most effective technology for converting sunlight to heat and electricity [9]. Hybrid photovolta- ic/thermal $(P V / T)$ system is a new system that combined photovoltaic panels with a solar collector in one system, which produces electrical and thermal energy simultaneously [10]. THE hybrid PV/T system consists of the PV solar panel to produce the electricity with an absorber plate behind the PV that extracts the heat and transfer it by the circulating fluid passing through pipes. Thus, it contributes to decreasing the PV's temperature and enhancing their efficiency; Figure 1 shows the schematic diagram of the PV/T system [11], [12]. Circulating the water or air in the back of the PV contributes to reducing the PV module's high temperatures. Thus maintaining the electrical efficiency and the heated fluid produce use for other applications [13]- [15]. Many studies have conducted air and water use as a cooling medium for the PV/T to reduce the temperature and raise the system efficiency [16], [17], with better performance than the PV alone [18]. However, the PV/T systems are relatively suffering from low efficiency due to the conventional heat transfer fluids [19].

Recently, significantly researchers used nanofluids in the $\mathrm{PV} / \mathrm{T}$ system because of its positive impact on the PV/T system's performance as a cooling fluid or optical filter [20]. Due to their high thermal properties, it was used as an alternative to conventional fluids [21]. Nanofluids have an appropriate property for heat transfer and absorption [22]. The authors [23]- [26] have investigated the influence of using nanofluids as a cooling fluid for the PV panel and apply in the solar systems. The nanofluid's high thermal conductivity has increased its uses as a heat transfer factor with the PV/T systems and the 


\section{Solar radiation}

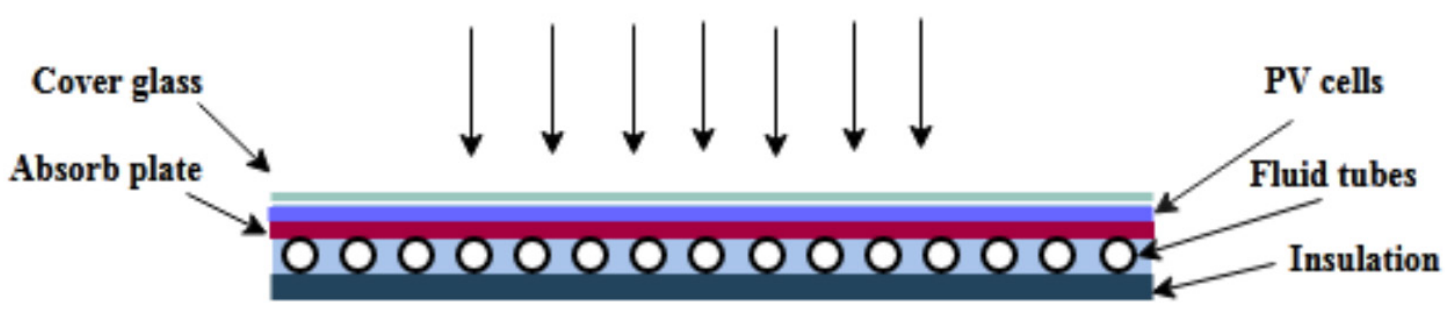

Figure 1: Schematic diagram of the hybrid PV/T system

heat exchangers [27]. Conventional fluids like water or oil used as heat transfer fluids have a lower thermal conductivity, which influences all sorts of heat exchangers' efficiency [28]. Therefore, using fluids with high thermal conductivity became important in thermal applications, which encouraged researchers to use nanofluids as an alternative to conventional fluid [29]. Other researchers studied the effect of using different types of nanoparticles on solar systems' performance that produce thermal and electrical energy or a hybrid PV/T system. Nevertheless, various researchers have achieved advanced results, using nanofluid as a working fluid that contributes to cooling the solar cells by extracting the excess heat and using it in thermal applications [30]. Thus, enhancement of the overall efficiency and increasing the performance of solar systems.

\section{NANOTECHNOLOGY}

Nanotechnology has a significant role in different fields, such as heat transfer processes and energy applications, where it has achieved remarkable progress. Nanotechnology's positive role can be exploited by using it as a working fluid to replace conventional fluids that remove the solar system's excess heat [31]. This review focuses on nanofluids' vital role in improving solar systems' efficiencies by increasing the thermal conductivity and heat transfer coefficient.

\section{Nanofluid}

Nanofluids are the term given for the stable dispersion of the nanometer-sized materials into base fluids [32]. In 1993 the concept of suspending nanoparticles with different fluids was adopted to improve heat transfer fluids. In 1995 the term nanofluid was applied as colloidal suspensions. Several theoretical and experimental studies on nanofluids' use found that the nanofluid has better heat transfer characteristics than other fluids [20]. Therefore, different definitions were found for the nanofluid in the literature. Still, most researchers agree to define the nanofluid as mixing nanoparticles with a diameter between 1 to $100 \mathrm{~nm}$ dispersed in the base fluid [8], [33]. Mixing the nanoparticles by the base fluid to produce nanofluid that is considered a new working fluid has distinctive properties that extract excess heat, especially from solar systems [34]. Enhance the heat transfer coefficient is an essential feature of nanofluid that leads to an increase in the thermal conductivity of the working fluid [35].

Therefore, to achieve significant performance using nanofluid, it requires preparation of nanoparticles with high stability and suspension within the base [36]. The most popular methods used to prepared nanoparticles are a single-step method that depends on the physical or chemical means to prepare. The two-step method is the second method to make nanoparticles mixed with the base fluid using either the high shear or ultrasound methods. Hence, direct or indirect ultrasonication has been used with the two-step method to ensure nanoparticles' stability inside the base fluid [37]. On the other hand, the hybrid nanofluids are produced during two methods; the first method is to add two different nanoparticle types into the basic fluid. The second one is the manufacture of nanocomposites and then dispersed in a basic fluid. The second method is complex and requires the different nanoparticles' stability to ensure its dispersion into the base fluid [38]. Wherever advantages have been founding, the disadvantages it noticed as well. The authors [34], [33] found that nanofluids' preparation has a high cost and observed nanofluids' unstable behavior at high temperatures. Thus, the agglomerate of nanoparticles leads to clogging of the fluid flow channel and the erosion of the system's metallic configurations.

\section{Type of nanoparticles}

Mixing the base fluid with low thermal conductivity with solid nanoparticles with high thermal conductivity leads to producing a new fluid and has high transfer characteristics higher than the base fluid [39], [40]. The nanoparticles are the essential factor of the nanofluid, which contributes after mixing with the base fluid to produce the nanofluids. Its improved thermal properties have wide use in various applications as cooling fluid. Different types of nanoparticles used metallic such as copper, silver, etc. and nonmetallic such as copper oxide, aluminum oxide, etc. Other types of carbon and nanocomposites, figure 2, show the different types of nanoparticles [36], [41]. Each type of nanoparticles has unique thermo-physical properties represented by thermal conductivity and thermal diffusivity in addition to viscosity [42]. Thus, the author [43] referred to enhancing absorption and increasing conversion efficiencies according to particle concentrations into pure water after mixing nanoparticles in the base fluid. 


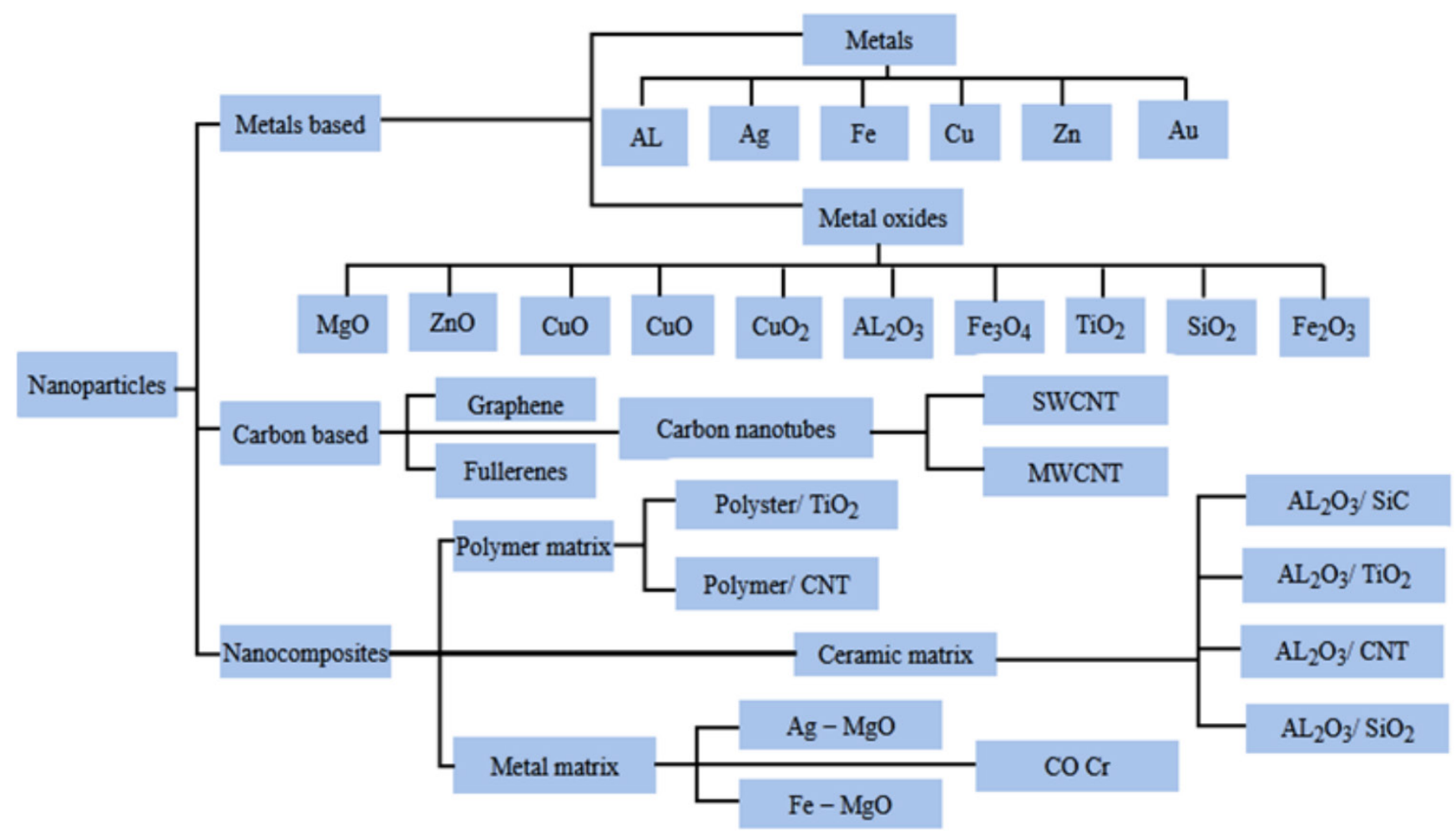

Figure 2: Type of nanoparticles

\section{Thermophysical properties of nanofluid}

The nanofluids' thermophysical properties represent the significant factors contributing to enhancing its properties and positively reflect on its performance. Several studies have investigated the influence of nanofluid's thermophysical characteristics on its performance. The effects of some parameters on the nanofluids thermophysical, such as temperature, base fluid, volume fraction, the nanoparticles concentration, etc. Nanofluid density is an essential property that significantly affects the system's sustainability and achieves a suitable extent of nanofluid stability [44], [45]. Therefore, an increase in nanofluids' density causes a robust effect on the pumping capacity [46]. Adding a surfactant contributes to a limited increase by the density of nanofluid [47]. The viscosity of nanofluid affects nanofluids' behavior and the capacity of the pumping power of the circulating of fluids [48], in addition to heat transfer characteristics [49]. Increasing the viscosity of nanofluid is linked with increasing surfactant concentrations [50], [51]. Based on the author [52], the volume concentration and temperature would control the viscosity, while the base fluid is the most important factor determining the nanofluid viscosity. The author [27] studied the effects of temperatures on nanofluids' density and found that rising temperatures led to nanofluid density reduction. Whereas the specific heat plays a vital role in providing the energy that transmits from a body to another [22]. In nanofluid, specific heat is different depending on the kind of nanomaterials used and their concentration in the base fluid in addition to the type of base fluids [24]. The specific heat increases with the ris- ing temperature, while the size of nanoparticles with its concentration and base fluids have a negative impact on the specific heat [53], [54]. Increasing the value of nanofluid's thermal conductivity is required to enhance the heat transfer nanofluid applications [55]. A review of both [49], [56] proven the increase in the temperature with nanoparticle concentration contributes by increasing nanofluid's thermal conductivity. According to a study conducted on nanofluids' thermal behavior, increasing the thermal conductivity is mainly associated with the nanoparticles' size and the type of nanoparticle material with its concentration in the base fluid [57]. Hence, adding the surface modifiers has a limited influence on nanofluid's thermal conductivity [58].

\section{APPLICATIONS OF NANOFLUIDS IN THE HYBRID PVIT SYSTEMS}

Recently, applying nanofluids in the hybrid PV/T systems has attracted many researchers to improve the system's performance. The lower efficiency of the PV/T systems resulting from using conventional fluids has encouraged nanofluids to improve heat transfer properties. Adding nanoparticles to conventional fluids has improving its thermal properties, which leads to enhancing efficiency [19], [21]. Using nanofluids contributes to the extraction excess of the PV system's heat and use it in other applications. Thus cooling the PV system by the nanofluid will increasing electricity generation of the PV system [59]. Numerous researchers have use nanofluids with the PV/T systems in two ways, for coolant of the PV/T system and as a spectral filter, or combine both of them, as shown in figure 3 [18]. An experiment conducted by 

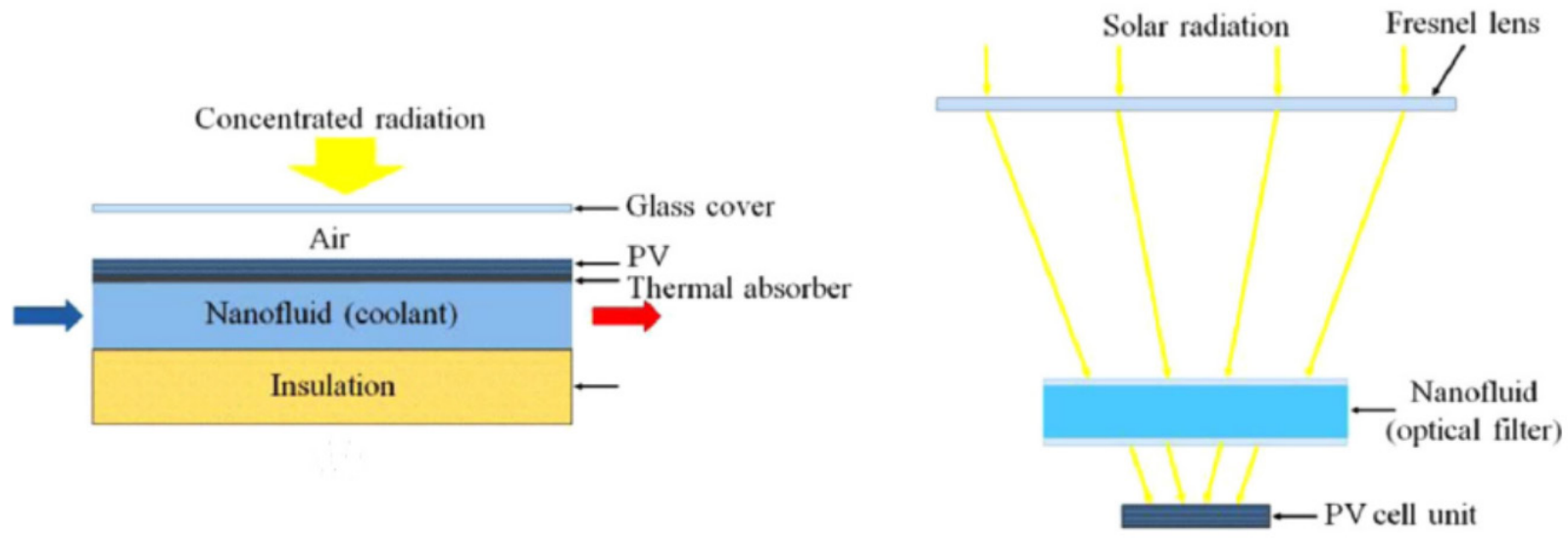

Figure 3: Schematic of the PV/T system with nanofluid as a coolant and spectral [60]

[61] that used nanofluid with a PV/T system with a certain percentage of nanoparticles leads to an increase the electrical efficiency higher than the PV system alone. Thermal efficiency has increased compared with cooling water, thus increasing the system's overall efficiency.

A new technique has used mirrors to concentrate the sunlight on the PV system, as shown in figure 4, using nanofluids to increase the electrical and thermal efficiencies of the concentrated PV/T system (CPV/T). Both authors [62], [63] indicate that using nanofluid as a cooling fluid and optical filter had a noticeable effect on the CPV/T system's overall efficiencies. Many researchers have concentrated on uses different sorts of nanoparticles, such as (metal, metal oxide, etc.), to improve the $\mathrm{PV} / \mathrm{T}$ system.

Various studies were conducted on improving the PV/T performance using different types of nanofluids, base fluids with different designs of PV/T systems, as shown in Table 1, to increase the system's electrical and thermal efficiency.

\section{Use metal-based nanoparticles as a working fluid in the PV/T system}

Recently, many studies and researchers used metal-based nanoparticles that mix with the base fluids to enhance the PV/T system's performance. Glazed and unglazed hybrid $\mathrm{PV} / \mathrm{T}$ systems have been designing with a direct copper absorber plate to the PV cells to study the system's efficiency, where use $\mathrm{Cu} /$ water as a nanofluid that flows in one rectangular channel. The results refer to enhancing the thermal efficiency with used $\mathrm{Cu} /$ water, while electrical efficiency has decreased along with glazing [65]. A study conducted on the effects of dispersing different sorts of nanoparticles during various conventional base fluids has proven added Cu nanoparticles to water leads to an increase in the PV/T system's efficiency more than use ethylene glycol [66]. The analysis was conducted with CFD on the PV/T system with the use of Ag-water and AL-water as nanofluids to recognize the system's behavior. The results appeared to increase the heat transfer coefficient and efficiency by increasing the volume of a fraction of the nanofluid. Increasing the volume of a fraction $(\varnothing)$ at $5 \%$ leads to an increase in the AL-water nanofluids' heat transfer coefficient about $2 \%$ and the inlet velocity. At the same time, Ag-water had exhibited a higher increase in the heat transfer coefficient [10]. A study done by [67] used nanofluids to reduce the PV panel's temperatures and enhance the system's efficiency. Ag and Cu nanoparticles have been using, where Ag nanoparticles had a better effect than $\mathrm{Cu}$ nanoparticles. Whereas Ag-water nanofluid using on the system has a greater influence on performance than $\mathrm{Cu} /$ water use. An experiment has used $\mathrm{Ag}$ and Au nanoparticles for cooling and optical purposes with the PV/T systems. The finding revealed that select $\mathrm{Ag}$ nanoparticles have

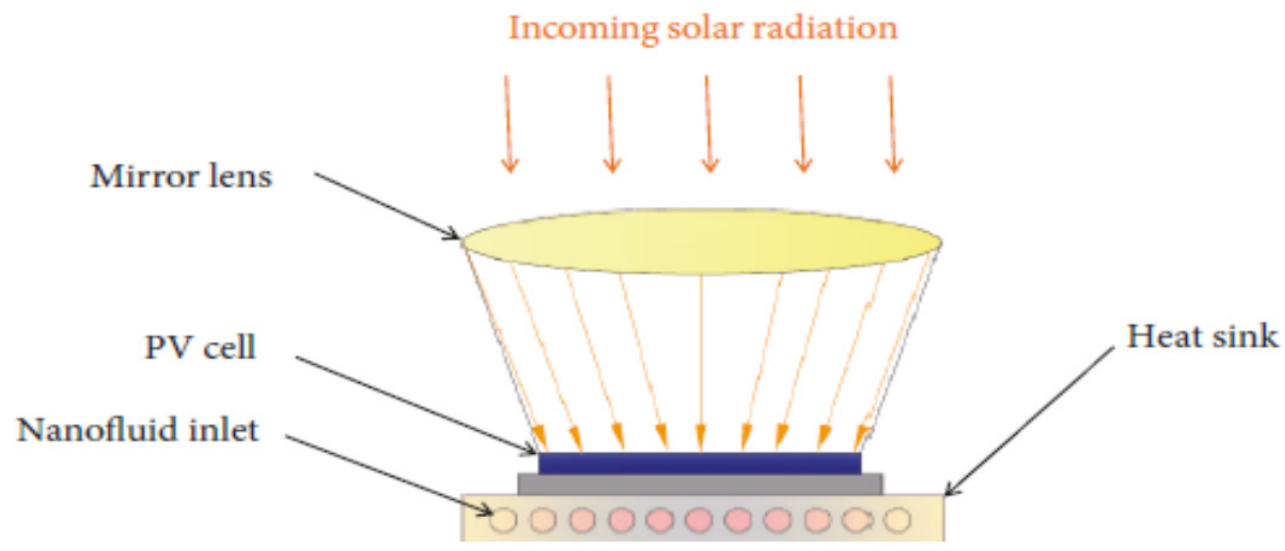

Figure 4: Schematic diagram of the CPV/T system work on nanofluid [64] 
Table 1: Some studies related to the usage of nanofluids with PV/T applications

\begin{tabular}{|c|c|c|c|c|}
\hline Ref. & Type nanoparticles & Base fluid & Application & Outcomes \\
\hline [20] & $\begin{array}{l}\text { Metal oxide-based } \\
\text { nanoparticles }\end{array}$ & $\begin{array}{l}\text { Water, ethylene } \\
\text { glycol-water }\end{array}$ & $\mathrm{PV} / \mathrm{T}$ & $\begin{array}{l}\text { The use of nanofluids with hybrid PV/T systems applica- } \\
\text { tions improves the system's performance, whether with the } \\
\text { laminar or turbulent regime. Nanoparticles with a larger di- } \\
\text { ameter positively influence overall energy efficiency in the } \\
\text { laminar regime, while opposite that with the turbulent re- } \\
\text { gime. Moreover, it observed that aluminum oxide/water has } \\
\text { higher system performance than titanium oxide. Nanofluid } \\
\text { that adopting water as a base fluid contributes to increased } \\
\text { energy and exergy efficiency more than ethylene glycol } \\
\text { used as a base fluid. }\end{array}$ \\
\hline [22] & $\begin{array}{c}\text { Metal-based, } \\
\text { oxide-based } \\
\text { nanoparticles and } \\
\text { carbon-based } \\
\text { nanoparticles }\end{array}$ & $\begin{array}{c}\text { Different type of } \\
\text { base fluids }\end{array}$ & $\mathrm{PV} / \mathrm{T}$ & $\begin{array}{l}\text { The use of nanofluids helps enhance the PV/T system's } \\
\text { performance. It raises the total solar energy yield and in- } \\
\text { creases the system's thermal energy compared with con- } \\
\text { ventional fluids. However, nanofluids have contributed to } \\
\text { enhanced heat transfer as a base fluid in the PV/T system, } \\
\text { thus increasing electrical and thermal efficiencies. }\end{array}$ \\
\hline [18] & $\begin{array}{l}\text { Metal-based, } \\
\text { oxide-based } \\
\text { nanoparticles and } \\
\text { carbon-based } \\
\text { nanoparticles }\end{array}$ & $\begin{array}{l}\text { Water, ethylene } \\
\text { glycol }\end{array}$ & $\begin{array}{l}\mathrm{PV} / \mathrm{T} \\
\mathrm{CPV} / \mathrm{T}\end{array}$ & $\begin{array}{l}\text { According to various types of PV/T systems that used nano- } \\
\text { fluids or other fluids, the studies concluded that used nano- } \\
\text { fluids have improved thermal conductivity, which positive- } \\
\text { ly impacts the performance. Thus, the possibility for used } \\
\text { nanofluid as an optical filter or for cooling in the PV/T sys- } \\
\text { tems because of nanofluids' high thermal properties, which } \\
\text { appeared higher efficiency in the PV/T system than other } \\
\text { fluids. }\end{array}$ \\
\hline [8] & $\begin{array}{c}\text { Metal-based, } \\
\text { oxide-based } \\
\text { nanoparticles }\end{array}$ & $\begin{array}{l}\text { Water, ethylene } \\
\text { glycol }\end{array}$ & $\begin{array}{l}\mathrm{PV} / \mathrm{T} \\
\mathrm{CPV} / \mathrm{T}\end{array}$ & $\begin{array}{l}\text { Use nanofluid as an alternative for the conventional liquids } \\
\text { as work fluid or optical filtration as a cooling for the PV/T } \\
\text { system leads to high enhancement in the system's perfor- } \\
\text { mance. Also, using some modifications in the system's de- } \\
\text { sign, like using honeycomb in the backside of the PV panel } \\
\text { instead of the channel's cross-section, has contributed to } \\
\text { enhancing the thermal load distribution. }\end{array}$ \\
\hline [71] & $\begin{array}{l}\text { Oxide-based } \\
\text { nanoparticles }\end{array}$ & Water & PV & $\begin{array}{l}\text { A study was conducted on the PV module's performance } \\
\text { using cotton wick structures that fixed at the back of the PV } \\
\text { module using nanofluids as cooling fluid. The results refer } \\
\text { to increasing the PV module temperature up } 65^{\circ} \mathrm{C} \text { without } \\
\text { cooling. } \\
\text { Using water with the cotton wick as a cooling contributes to } \\
\text { lowering } \mathrm{PV} \text { 's temperature up } 45^{\circ} \mathrm{C} \text {. While using both } \mathrm{CuO} / \\
\text { water and } \mathrm{Al}_{2} \mathrm{O}_{3} \text { /water as nanofluids reduce the tempera- } \\
\text { ture of the } \mathrm{PV} \text { module about } 59^{\circ} \mathrm{C} \text { and } 54^{\circ} \mathrm{C} \text {, that is lower } \\
\text { than using water as cooling with cotton wick structures and } \\
\text { that because of the adherence of nanoparticles by the wick } \\
\text { fibers, which natively influence in wick structures. }\end{array}$ \\
\hline
\end{tabular}

the best effect on conventional fluids used in PV/T systems. Therefore, for cooling and optical filtering, using $\mathrm{Ag} /$ water nanofluid has achieved higher thermal and overall efficiency than Au-water and Cu-water [68]. Using Ag-water nanofluid as a coolant in separate channels in $\mathrm{PV} / \mathrm{T}$ was better than the double-pass channel. Increasing volume fraction leads to rising the overall efficiencies of the PV/T system [69].

A comparison has conducted by [70] between $\mathrm{Cu}$ and $\mathrm{AL}$ nanofluids to recognize the thermal conductivity enhancement at $1 \%$ volume fraction, and nanoparticle size was $80 \mathrm{~nm}$. The results revealed Cu nanofluid has higher thermal conductivity than AL nanofluids [71], as shown in figure 5 (A). To improve nanofluids' thermal conductivity, ethylene glycol-based Fe nanofluids have prepared using sonication at high powered pulses. Compared with Cu nanofluids, it observed nonlinear function with volume fraction, increasing the thermal conductivity as reaching $18 \%$, as shown in figure 5 (B). Thus, Fe nanofluids' conductivity is improved more than $\mathrm{Cu}$ nanofluids because Fe nanofluids are efficient in thermal transport [72]. An active cooling technique had used by [73] to enhance the performance of the PV panels, Zn-water nanofluid used as a work fluid passing during small heat exchanger placed in the back of the PV panels, with different concentration ratios $\mathrm{Zn}$ have used. The results appear to reduce the PV panels' temperature by increasing the electrical efficiency with a concentration ratio of $0.3 \%$. 

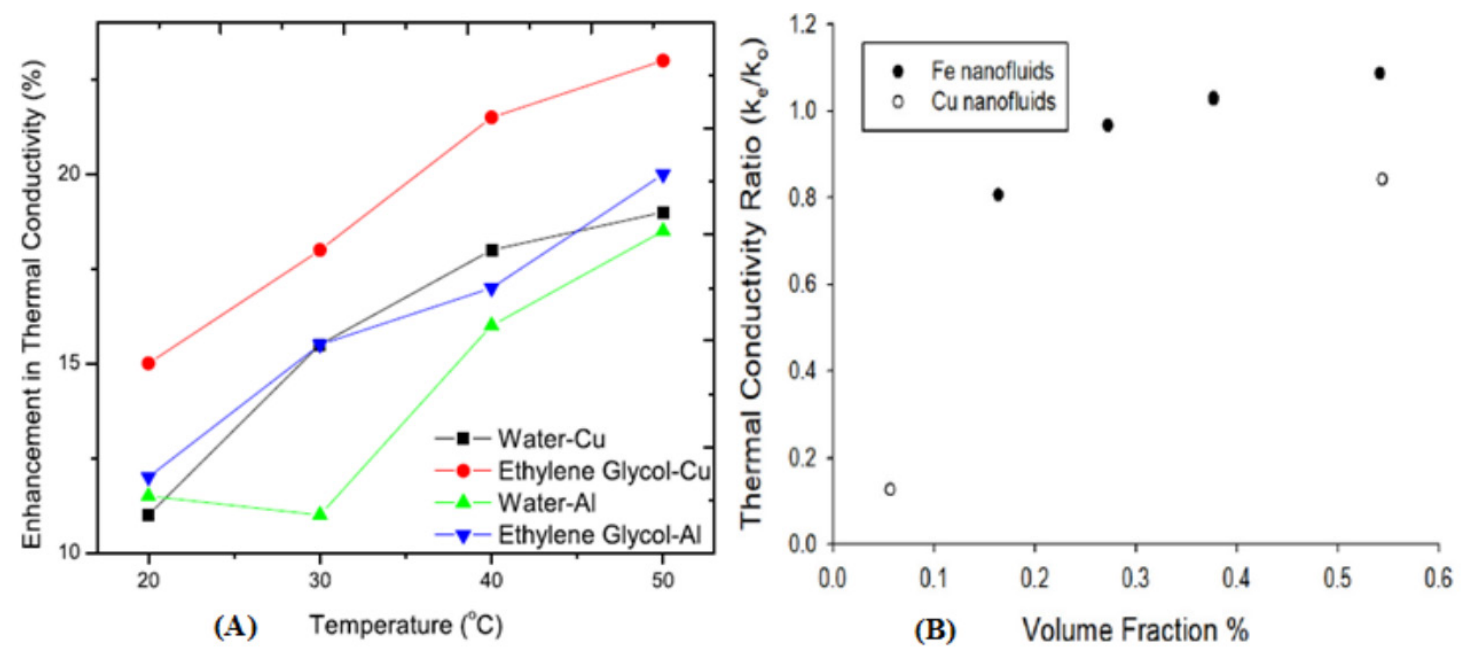

Figure 5: (A) The relationship between $\mathrm{Cu}$ and $\mathrm{Al}$ with different base fluids and enhancement in thermal energy,

(B) The relationship between volume fraction and the thermal conductivity of $\mathrm{Fe}$ and Cu nanofluids [74]

\section{Use metal oxide-based nanoparticles in the PV/T system}

Other experimental and numerical studies have been conducting on the use of metal oxide-based nanoparticles mixed with various sorts of base fluid to recognize nanofluids' effect on the PV/T system's efficiencies.

Aluminum oxide $\left(\mathrm{AL}_{2} \mathrm{O}_{3}\right)$

Several researchers adopted metal oxide of nanoparticles after mixing with the base fluids as a nanofluid. The author [75] has investigated the use of $\mathrm{AL}_{2} \mathrm{O}_{3}$-water with the $\mathrm{PV} / \mathrm{T}$ system to study the influence $\mathrm{AL}_{2} \mathrm{O}_{3}$-water with various concentrations began $(0.1,0.2,0.3,0.4$, and $0.5 \%)$. The investigation results show reducing temperature to $42.2{ }^{\circ} \mathrm{C}$ with an increase the electrical efficiency to $12.1 \%$ at $0.3 \%$ of $\mathrm{AL}_{2} \mathrm{O}_{3}$ concentration. $\mathrm{A}$ higher than $0.3 \%$ concentration ratio leads to a rising temperature with lower electrical efficiency again. A simulation study of the PV/T system for the one-way channel placed behind the $\mathrm{PV} / \mathrm{T}$ system, $\mathrm{AL}_{2} \mathrm{O}_{3} /$ water used as a working fluid with the volume of a fraction $\varnothing(0 \%$ to $10 \%)$. The results show a lower Reynolds number to 5 has contributed to enhancing the heat transfer rate to $27 \%$ at $\varnothing=10 \%$ volume of a fraction [76]. Study the impact of using different concentrations of nanoparticles (1 wt. \%, $1.5 \mathrm{wt} . \%$, and 2 wt. \%) of $\mathrm{AL}_{2} \mathrm{O}_{3}$ as a nanofluid with the PV/T system. Thus, both thermal and electrical efficiencies have increased by $27.3 \%$ and $1.1 \%$ at used $1.5 \mathrm{wt}$ \% nanoparticle concentration, which was considered optimum values, with a $50 \%$ filling ratio [77]. Author [78] indicates using 1.2 wt. $\%$ nanoparticle concentration of $\mathrm{AL}_{2} \mathrm{O}_{3}$ nanofluid and $40 \mathrm{~L} / \mathrm{H}$ mass flow rate has increased the thermal efficiency by $58 \%$, electrical efficiency by, $45 \%$ the overall efficiency by $13 \%$, respectively.

Furthermore, Using $\mathrm{AL}_{2} \mathrm{O}_{3}$ /water as a nanofluid that passes during the rectangular channel in the PV/T system causes an increased heat transfer rate with a dropped PV temperature [76]. Hence, enhancing both the electrical and overall efficiencies while there is no significantly varying thermal efficiency [79], [80]. Another study used $\mathrm{AL}_{2} \mathrm{O}_{3}$ /water as a nanofluid that flows over the PV cells instead of water, increases thermal and overall efficiency. Increment visible light that was absorbed by nanofluids has caused a decrease the electrical efficiency [81]. An experimental study by [82] used $\mathrm{AL}_{2} \mathrm{O}_{3}$-water as a cooling fluid with forced convection. Nanofluid concentrations used were $(0.1,0.2,0.3,0.4$, and 0.5); when the water used, the PV temperature was $79.1{ }^{\circ} \mathrm{C}$. The temperature dropped with used variable concentrations of $\mathrm{AL}_{2} \mathrm{O}_{3}$-water, where it reached $42.2{ }^{\circ} \mathrm{C}$ at a $0.3 \%$ concentration ratio.

\section{Silicon oxide $\left(\mathrm{SiO}_{2}\right)$}

To avoid the rising of the $\mathrm{PV} / \mathrm{T}$ system temperature, $\mathrm{SiO}_{2} /$ water was used as a coolant and maintaining the system's efficiency, with used 1 and $3 \%$ by weight of mass fractions. The study refers to an increased thermal and energetic efficiency of about $12.8,24.31 \%$ at $3 \mathrm{wt}$. \%, while overall efficiency increased $3.6,7.9 \%$ with used 1 and $3 \%$ by weight of mass fractions [83]. The PV/T system's performance has been studying with different types of nanofluids [84]. The results indicate that using $\mathrm{SiO}_{2}$ as working fluids has achieved better performance with enhancing the thermal and electrical efficiencies than other nanofluid or water [85]. It was used different

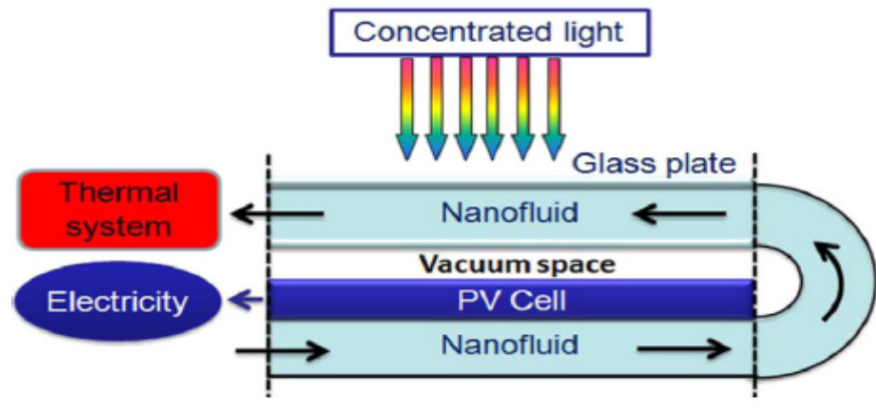

Figure 6: Decoupled PV/T system use nanofluid as a working fluid 
sizes of $\mathrm{SiO}_{2}$ nanoparticles from 11-14nm with 1, 3 wt. $\%$ concentration mixed with water as nanofluids for cooling the PV/T system. The experimental results revealed improving the exergy efficiency and energy of the PV/T system [86].

The decoupled PV/T system has designed using $\mathrm{SiO}_{2}$ nanoparticles as a sol-gel method, as shown in figure 6. Another experimental study was conducted to use $\mathrm{SiO}_{2} /$ water nanofluids as a coolant and spectral filter the system; a $2 \%$ volume concentration adopted with used a variety of sizes between $5 \mathrm{~nm}$ to $50 \mathrm{~nm}$. Therefore, used $0.015 \mathrm{~L} / \mathrm{s}$ of flow rate, $5 \mathrm{~nm}$ particle size, and $2 \%$ volume concentration, the system's energetic efficiency has increased $7 \%$ compared to water [59]. The percentage proportion of nanoparticles weight uses have notably on the efficiencies of the PV/T systems. An investigation was conducted on the influence of $\mathrm{SiO}_{2}$-nanofluid by the $\mathrm{PV} / \mathrm{T}$ system as a coolant to enhance the system's efficiencies, where different proportions of $1 \%$ wt. $\%$ and $3 \%$ wt $\%$ have tested. Using $1 \mathrm{wt} \%$ from the silica-water nanofluid has increased the system's overall efficiency to $3.6 \%$ with a thermal efficiency of $7.6 \%$, which is more effective than pure water. Thus using $3 \mathrm{wt}$. $\%$ of silica-water nanofluids has increased the overall efficiency to $7.9 \%$ while thermal efficiency $12.8 \%$ [83]. An experimental study was conducted by [87] on using $\mathrm{SiO}_{2}$-water nanofluid for coolant the CPV/T system. The experimental reported increase in the efficiency of the system even with high irradiance.

\section{Iron oxide $\left(\mathrm{Fe}_{3} \mathrm{O}_{4}\right)$}

Lowering the $\mathrm{PV}$ panel temperature is the main purpose that many studies focus on; various types of nanofluids were used to achieve a suitable level of efficiency. A study used two proportions, 1 and $3 \mathrm{wt} \%$ of mass concentrations of $\mathrm{Fe}_{3} \mathrm{O}_{4}$ - water under two values of solar radiation 600 and $1100 \mathrm{~W} / \mathrm{m}^{2}$ of solar radiation. The results revealed rising the electrical, thermal efficiency to $4.93 \%$, and $46.29 \%$, respectively. Thus, the overall efficiency until $76 \%$ at 3 wt. $\%$ compared with distilled water [88]. Other experiments used $\mathrm{Fe}_{3} \mathrm{O}_{4}$ /water nanofluid as a coolant in sheet and tube of the PV/T system; the concentration was $1,3 \mathrm{wt}$. \%, with size $45 \mathrm{~nm}$, the testing had done with a constant and alternating magnetic field. The results show improving the energy and exergy efficiency of the PV/T system by using ferrofluid with alternating magnetic field better than other conditions [59]. Another proposal by [89] used $\mathrm{Fe}_{3} \mathrm{O}_{4}$ nanoparticles as an optical filter in the PV/T system, as shown in figure 7, where the nanoparticles of magnetic $\mathrm{Fe}_{3} \mathrm{O}_{4}$ has dispersed with a $50 \%$ water $150 \%$ ethylene glycol and adding either methylene blue or copper sulfate. The test outcomes refer to good stability with the electrolyte nanofluid's better efficiency at used magnetic, optical filter compared to the conventional filters with smaller thickness. Thus, nanofluid's magnetic electrolyte leads to higher thermal conductivity at a limited range of temperatures.

\section{Titanium oxide $\left(\mathrm{TiO}_{2}\right)$}

A study was accomplished by [90] using $\mathrm{TiO}_{2} /$ water as a working fluid on the concentrated photovoltaic receiver. It has studied the influence of increasing the volume fraction and type of flow regime, concentration ratio, and pipe length. The nanofluids' thermal conductivity and viscosity have increased with decreasing the Reynolds number at a steady mass flow rate. Thus the temperature of the PV has dropped. Furthermore, there is a high increase in thermal, electrical efficiency, and overall efficiency compared to the laminar-turbulent flow, whereas using $\mathrm{TiO}_{2}$ nanoparticles cause enhancing the thermal performance, overall energy, and exergy efficiency of the system [91]. The author [20] studies the impact of volume fraction, the diameter of nanoparticles, and nanofluid outlet temperature in the $\mathrm{PV}$ system. $\mathrm{TiO}_{2} /$ water was used as nanofluid with diameters (21 and 100) nm at constant mass flow rates for both laminar and turbulent regime. The results show the PV's reduced temperature at added nanoparticles to the base fluid at laminar flow, an opposite observed with the turbulent regime.

\section{Copper oxide (CuO)}

Maintaining the PV system's efficiency at a specific lev-

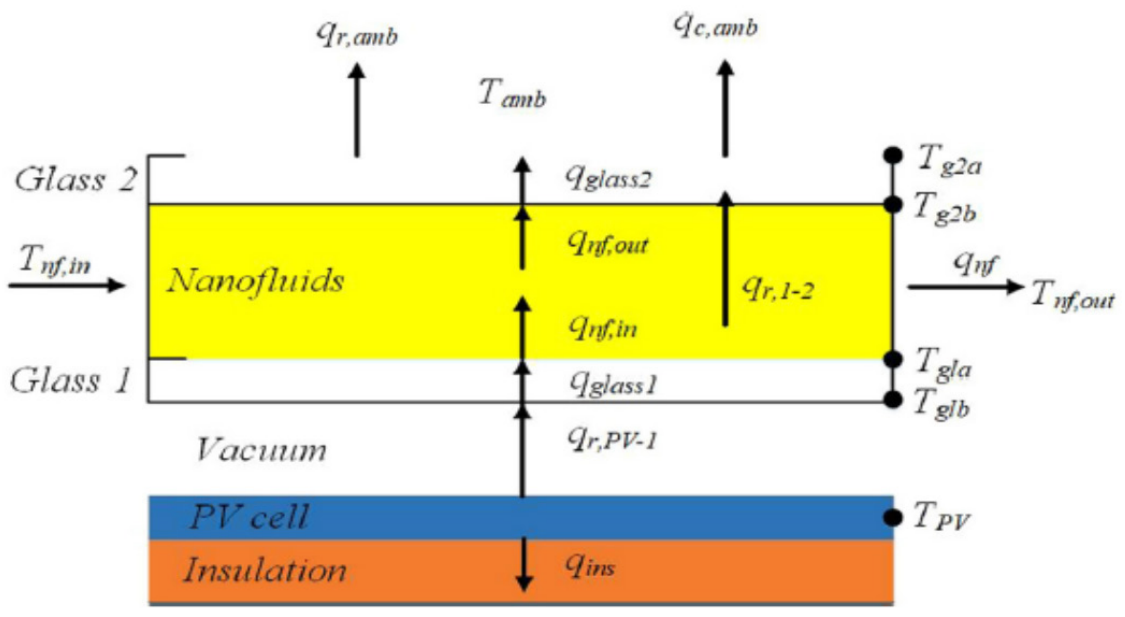

Figure 7: Schematic diagram of using optical filtration nanofluid for the PV/T system 


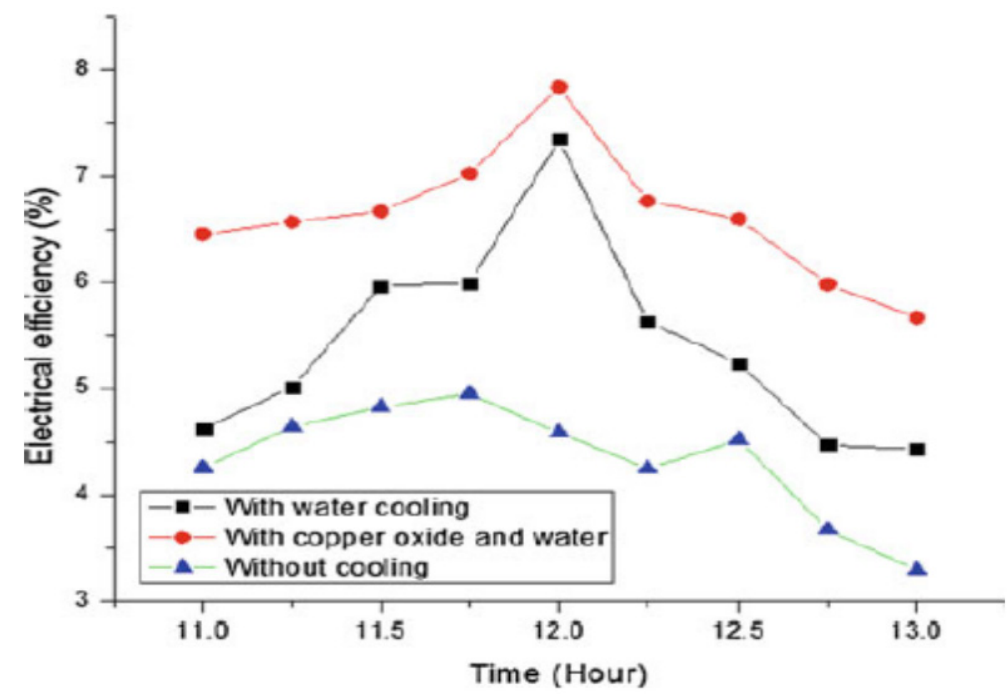

Figure 8: The behavior of the electrical efficiency with and without cooling

el that allows produces an adequate return is the focus of attention for many researchers. A study conducted by [92] on using copper oxide- water as a cooling fluid of the PV panel exposed to high-temperature reaches $55.5^{\circ} \mathrm{C}$. The results show reducing the temperature of the PV to $41^{\circ} \mathrm{C}$ when used copper oxide-water. The maximum electrical efficiency was $7.8 \%$, while the electrical efficiency was $7.3 \%$ at used pure water as a cooling fluid; figure 8 shows the PV panel's electrical efficiency with water cooling and without cooling and copper oxide-water for cooling. Thus used copper oxide-water leads to increase exergy efficiency to $57.78 \%$ compared to water. A numerical and experimental study was conducted using $\mathrm{CuO} /$ water to cool the PV/T system with a laminar flow regime. It observed decreased the PV panel temperature by $14.5^{\circ} \mathrm{C}$ using $\mathrm{CuO} /$ water nanofluid, with a $0.5 \%$ increase in electrical efficiency while the exergy was $57.78 \%$ [64].

Solidworks flow simulation was used to study the influence of using $\mathrm{CuO} / \mathrm{Sy}$ ltherm 800 to improve the CPV/T system's performance with a parabolic trough concentrator. The study has considered the effect of temperature range from 25 to 200 with 300 to $720 \mathrm{~L} / \mathrm{hr}$ of nanofluid flow rate on the thermophysical properties. The results revealed to enhancing all the system efficiencies, at 540 $\mathrm{L} / \mathrm{hr}$, there was a small improvement in thermal efficiency. The higher efficiency for both the thermal, electrical efficiency as well as the overall efficiency was at $100^{\circ} \mathrm{C}$ in the inlet with $540 \mathrm{~L} / \mathrm{hr}$ flow rate, the values of efficiencies were $4684,6.60 \%$, and $2.08 \%$, that was bigger than values which achieved when used pure oil only [92]. Another experimental study conducted by [93] replaced the Tedlar layer of the silicon cell with a thin copper sheet; Cuo/water nanofluid has been used for cooling to boost the system's performance; the volume fraction used was $0.05 \%$ with the use of glazing and without. The results indicate to increase in thermal efficiency to $45 \%$ when used glazing with nanofluid, while the electrical efficiency has dropped about $3 \%$.

\section{Zinc oxide ( $\mathrm{ZnO})$}

An investigation conducted used two types of working fluids ( $\mathrm{ZnO} /$ water and pure water) on the efficiency of the

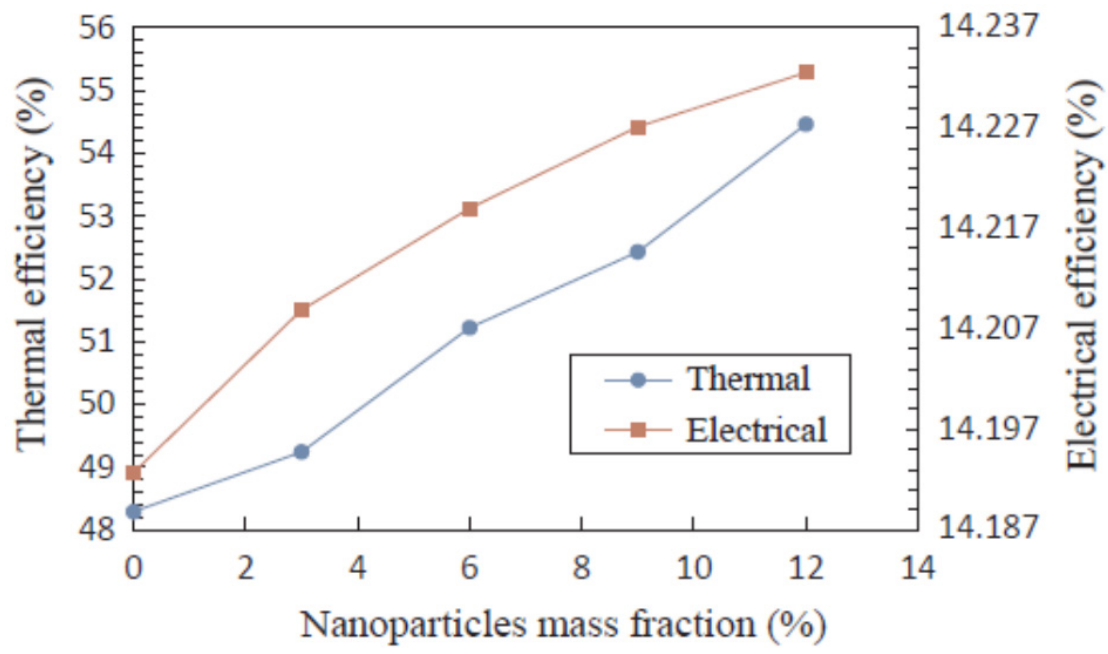

Figure 9: The effect of nanoparticles mass fraction on the efficiency of the PV/T system 
hybrid PV/T system using the Taguchi method to define the PV/T system's performance. ANSYS Fluent software was used to compare with the numerical results of the $3 \mathrm{D}$ numerical model. The result shows that using $\mathrm{ZnO} /$ water, the PV/T system's thermal efficiency has relatively enhanced compared with pure water. Thus a slight increasing the thermal efficiency by $1.97 \%, 6.07 \%, 8.57 \%$, and $12.78 \%$ with using $3 \mathrm{wt} \%, 6 \mathrm{wt} \%, 9 \mathrm{wt} \%$, and 12 wt $\%$ of nanoparticle mass fractions, as shown in figure 9, with limited improvement in the electrical efficiency [94]. According to different nanofluid types used to improve the $\mathrm{PV} / \mathrm{T}$ system's performance, using $\mathrm{ZnO} /$ water nanofluid gives better performance. Another possible effect on the PV/T system's electrical efficiency has been studying by [91] the influence of adding mass fraction between 0.05 to $10 \%$ wt of the $\mathrm{ZnO} /$ water. The study refers to increase the thermal efficiency four times while dropping both temperatures, the electrical efficiency $2 \%$, and $0.02 \%$.

\section{Magnesium oxide (MgO)}

A study conducted using MgO-Water nanofluid by the $\mathrm{PV} / \mathrm{T}$ system, where the nanofluid is flowing over the solar cells, the nanoparticle's size was around $10 \mathrm{~nm}$ with different concentrations. In contrast, the mass fractions used were $(0.02,0.06,0.1) \%$ wt. and film thickness of $10 \mathrm{~mm}$. The study indicates decreasing the transmittance of nanofluids with both the mass fraction and the film thickness. Increasing the mass fractions reduces the output power of the PV/T systems [95].

\section{Use combined metal and metal oxide nanoparticles in the PV/T system}

Recently several studies and researches using different sorts of metal oxide nanoparticles with varying fluids as nanofluids that flow by the pipes that were placed behind the PV/T system. A study was conducted by [91] on using a collection of metal oxide nanoparticles represented by $\mathrm{TiO}_{2}, \mathrm{AL}_{2} \mathrm{O}_{3}$, and $\mathrm{ZnO}$ with the impact of adding mass fraction. The study concluded that both $\mathrm{TiO}_{2}$ and $\mathrm{ZnO}$ have a good ability to enhance electrical efficiency than $\mathrm{AL}_{2} \mathrm{O}_{3}$. The thermal efficiency has a big value when used $\mathrm{ZnO}$ compared with $\mathrm{AL}_{2} \mathrm{O}_{3}$ and $\mathrm{TiO}_{2}$. Therefore, the temperature dropped by $2 \%$ and $0.02 \%$ of the electrical efficiency, while thermal efficiency increased four times when the addition mass fraction from $0.05 \mathrm{wt}$ to $10 \% \mathrm{wt}$ of $\mathrm{ZnO}$. The author [71] developed a simple passive cooling for the $\mathrm{PV}$ panel by cotton wick structures, as shown in figure 10 , using both $\mathrm{CuO} /$ water and $\mathrm{AL}_{2} \mathrm{O}_{3} /$ water nanofluid with a concentration of $\mathrm{CuO} /$ water, and $\mathrm{AL}_{2} \mathrm{O}_{3}$ /water was $0.1 \mathrm{wt}$ \%). The finding indicates the PV panel's efficiency was $10.4 \%$ with wick structures in and water, while the efficiency was $9 \%$ without cooling. Using $\mathrm{AL}_{2} \mathrm{O}_{3} /$ water and $\mathrm{CuO} /$ water with wick structures, the efficiency was $9.7 \%$ and $9.5 \%$.

Furthermore, an experimental investigation using two types of $\mathrm{SiO}_{2}$-water and $\mathrm{Fe}_{3} \mathrm{O}_{4}$-water nanofluids for cool-

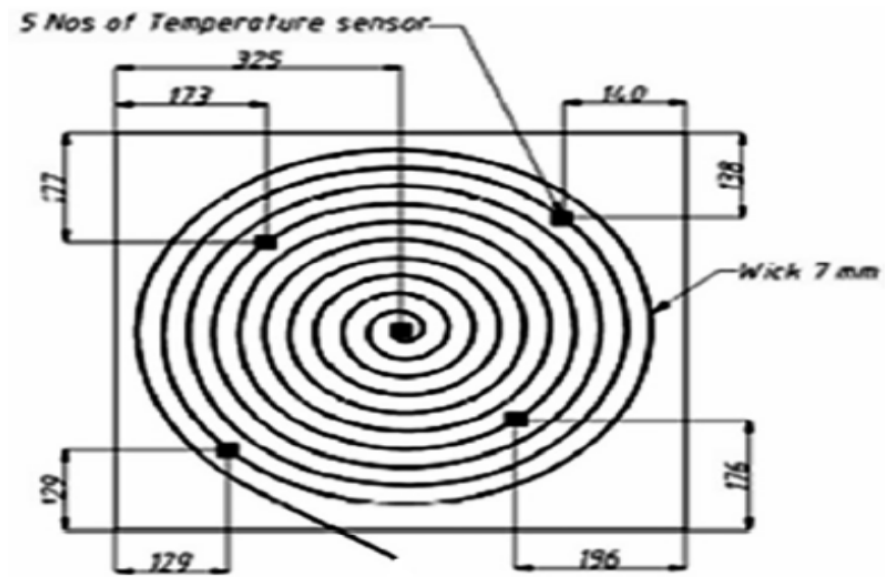

Figure 10: Cotton wick structures fixed in the back of the PV

ing the hybrid PV/T system. The results show a good influence by the thermal and electrical efficiency more than using water only. Thus, using $\mathrm{SiO}_{2}$-water nanofluid gives better efficiency than $\mathrm{Fe}_{3} \mathrm{O}_{4}$-water by $3 \%-4 \%$ [96]. Using $\mathrm{AL}_{2} \mathrm{O}_{3}$ /water and $\mathrm{CuO} /$ water nanofluids as a working fluid contributed to increased thermal efficiency by $21.30 \%$ and the electrical efficiency by $0.07 \%$ at using $\mathrm{CuO} /$ water compared with water only [97]. An experiment on the PV/T systems' performance was conducted by [98] using nanofluids in turbulent and laminar flow regimes. $\mathrm{Al}_{2} \mathrm{O}_{3}$ /water and $\mathrm{TiO}_{2}$ /water have tested at volume fractions from (0-4\%), with a diameter of particles between (21and 100) nm. It found enhancing the system's performance using nanofluids and noticed that $\mathrm{AL}_{2} \mathrm{O}_{3}$ nanoparticles have good thermal characteristics more than $\mathrm{TiO}_{2}$. The mathematical models have been simulating by [99] used ANSYS FLUENT ${ }^{\circledR}$ software, CFD, and MATLAB ${ }^{\circledR}$ to select the better nanofluid for the PV/T system. The nanoparticles $\mathrm{SiO}_{2}, \mathrm{AL}_{2} \mathrm{O}_{3}$, and $\mathrm{CuO}$ that used dispersed in the water with different concentrations. The results indicate that $\mathrm{CuO}$ nanofluid has higher thermal conductivity with better thermal stability than $\mathrm{SiO}_{2}$ and $\mathrm{AL}_{2} \mathrm{O}_{3}$. Also, use $\mathrm{CuO}$ nanofluid with both air and water leads to efficiency reach $90.3 \%$ and $79.8 \%$. In contrast, the author [100] studies the impact of using $\mathrm{AL}_{2} \mathrm{O}_{3}$ /water, $\mathrm{ZnO} /$ water, and $\mathrm{TiO}_{2} /$ water nanofluids on the energy and exergy of the PV/T system. The results show that used $\mathrm{ZnO}$ and $\mathrm{TiO}_{2}$ in the $\mathrm{PV} / \mathrm{T}$ system have better total energy efficiency and exergy efficiency than others.

\section{Use carbon-based nanoparticles in the PV/T system}

Several researchers have used carbon-based nanoparticles of both types of single-wall carbon nanotubes (SWCNT) multi walls carbon nanotubes (MWCNT) in different solar energy applications. water-MWCNT has been using with the PV/T system as a heat absorption and heat storage with the influence of volume concentration ratio $(0 \%$ to $0.3 \%)$ at a constant flow rate of $1.2 \mathrm{l} / \mathrm{min}$. [101] The experimental results indicate enhancing the thermal and electrical efficiency of the PV/T system due to used $0.075 \% \mathrm{~V}$ from MWCNTs, which leads to a drop 
in the temperature of the PV panel to $12{ }^{\circ} \mathrm{C}$. Hence, the overall efficiency was $83.26 \%$; the average temperature drops during daytime reached $10.3^{\circ} \mathrm{C}$ and the total efficiency of around $61.23 \%$. To improving the PV/T system's performance, a water/MWCNT nanofluid has been using as active cooling. COMSOL Software Multiphysics used 3D numerical simulation with different solar radiation values from $200-1000 \mathrm{~W} / \mathrm{m}^{2}$, the mass flow rate constant at $0.5 \mathrm{~L} / \mathrm{min}$, inlet temperature $32{ }^{\circ} \mathrm{C}$, and weight fraction (0 to $1 \%$ ). The numerical and experimental results refer to the PV/T system's overall efficiency were 89.2 and $87.65 \%$ with nanofluid use at $1000 \mathrm{~W} / \mathrm{m}^{2}$. It found the PV performance was $9.2 \%$ when using water as the cooling system, while the thermal performance was higher, about 4 and $3.67 \%$ in both numerical and experimental studies [102]. Another numerically and experimental investigation conducted by [103] using COMSOL software to check the results obtained from an indoor experimental uses MWCNT-water to improve the PV panel's efficiency. Fixed the value of solar radiation at $1000 \mathrm{~W} / \mathrm{m}^{2}$ and different mass flow rates between 30 to $120 \mathrm{l} / \mathrm{h}$. PV's electrical efficiency has improved by about $12.25 \%$ at $120 \mathrm{~L} / \mathrm{h}$ of mass flow rate with nanofluid concentration MWCNT-water by $0.75 \%$ wt. The PV panel temperature decreased to $0.72{ }^{\circ} \mathrm{C}$, with a rising volume flow rate to $10 \mathrm{l} / \mathrm{h}$, which leads to improving the thermal storage to $6.89 \mathrm{~W}$.

\section{CRITICAL ANALYSIS}

The hybrid PV/T system is widely employed by producing thermal and electrical energy, but these systems still need to develop to improve its performance. Several researchers have used different nanofluids as a working fluid to enhance the PV cells' performance and thermal energy. Using nanoparticles with base fluids as nanofluids achieved encouraging results by a remarkable increase in the PV/T system's overall efficiency. During the review, there is some hiatuses have noticed can summarize as follows:

- $\quad$ Regarding types of nanoparticles, many researchers used various nanoparticles with base fluids as nanofluids, but not all the types. It found very limited use of some types of nanoparticles, for instance, (Au, $\mathrm{MgO}$, and SWCNT) nanoparticles, and other types can barely mention their use, such as $\left(\mathrm{Fe}_{2} \mathrm{O}_{3}, \mathrm{CuO}\right)$.

- The contrasts have been founding regarding improved thermophysical properties of nanofluids, which affect the system efficiency. The control by some parameters as (concentration, disperse, volume fraction, size, addition surfactants, shape) of nanoparticles, etc., leads to enhancing the properties of nanofluids and, at the same time, reducing other properties. Therefore, resulted increase the thermal efficiency, with slightly improved electrical efficiency.

- Regarding operational conditions, many of the experiments and studies conducted under the climates considered somewhat moderate in terms of weather conditions. The experiments must conduct in the hot regions when the temperature reaches $50{ }^{\circ} \mathrm{C}$ and solar radiation more than $1000 \mathrm{~W} / \mathrm{m}^{2}$ to recognize nanofluids' behavior as a cooling fluid use with the PV/T system.

\section{CONCLUSIONS}

This review appears the potential of using nanofluids as a working fluid with the $\mathrm{PV} / \mathrm{T}$ systems instead of the conventional liquids improves the hybrid PV/T system's efficiency. Several studies and researchers have used different nanofluids with different PV/T systems designs to improve performance. Most of the studies that used nanofluids have achieved encouraging results by enhancing the PV/T systems' performance. Therefore, using nanofluids as a cooling fluid will contribute to an increase in the electrical and thermal energy of the PV/T system by removing excess heat of the PV cells by cooling it, which contributes to the stability of its work and increase its productivity. Furthermore, nanofluids' thermophysical properties play an intrinsic role by enhancing nanofluids' performance, thus positively reflecting on the PV/T system performance. Other conclusions can be drawn from the review as follows:

- Rising temperatures have a significant effect on nanofluids' thermophysical properties, where both the density and viscosity of nanofluids are reduced with increasing temperature and increase with added surfactant. On the other side, nanofluids' specific heat increases with temperature increase, while the volume fraction causes a decrease in nanofluids' specific heat. Adding the surfactant quantity has a slight reduction in the thermal conductivity of nanofluid. Increase both temperature and nanoparticle concentrations lead to improve the thermal conductivity of nanofluids.

- Most of the applications have used nanofluids in the $\mathrm{PV} / \mathrm{T}$ systems in two ways, either for coolant of the $\mathrm{PV} / \mathrm{T}$ system and as a spectral filter or combine both. Using a certain proportion of nanoparticles leads to an increase the electrical efficiency higher than the PV system alone.

- Using metal nanoparticles with base fluids as a nanofluid leads to enhancing the PV/T system's performance in varying proportions. Some of the nanoparticles improve the PV/T system's thermal efficiency, while electrical efficiency has decreased. On the other hand, used another type of metal nanoparticles has improved both thermal and electrical efficiency. Other researchers found a better performance of the PV/T system with used metal oxide nanoparticles by control in the parameters such (volume fraction, the concentration of nanoparticles, disperse of nanoparticles, size of nanoparticles, the shape of nanoparticles, addition surfactants, etc.).

- Using combined metal and metal oxide nanoparti- 
cles mixed with base fluid produces new nanofluids that have good features that enhance thermal conductivity and reduce PV cells' temperatures. Hence, improving the overall efficiency and exergy energy of the PV/T system. Moreover, use carbon-based nanoparticles mixed with a base fluid to boost the thermal and electrical efficiency of the PV/T system. Thus, it contributes by absorbing the PV's high temperature and improving the PV/T system's thermal storage.

\section{REFERENCE}

1. Kazem HA, Al-Waeli AH, Chaichan MT, Al-Mamari AS, Al-Kabi AH. (2016). Design, measurement and evaluation of photovoltaic pumping system for rural areas in Oman. Environ Dev Sustain. 1-13pp, http:// dx.doi.org/10.1007/s10668- 016-9773-z.

2. R. B. Ganvir, P. V. Walke, V. M. Kriplani. (2017). Heat transfer characteristics in nanofluid - A review. Renewable and sustainable energy reviews, 75, 451460

3. Mohammed Al-ktranee, PeterBencs. (2020). Overview of the hybrid solar system. Analecta Technica Szegedinensia journal,Vol. 14, 1.100 -108, doi: 10.14232/analecta

4. Browne MC, Norton B, Mccormack SJ. (2016). Heat retention of a photovoltaic/thermal collector with PCM, Sol Energy, 133:533-48. https://doi. org/10.1016/j. solener.2016.04.024

5. Hasan A, Mccormack SJ, Huang MJ, Sarwar J, Norton B. (2015). Increased photovoltaic performance through temperature regulation by phase change materials: materials comparison in different climates, Sol Energy 2015;115:264-76. https://doi.org/10. 1016/j.solener, 02.003

6. Odeh S, BehniaM.(2017). Improving photovoltaic module using water cooling, Taylor Fr,7632. https:// doi.org/10.1080/01457630802529214

7. Naseem Abbas, Muhammad Bilal Awan, Mohammed Amer, Syed Muhammad Ammard, UzairSajjad, Hafiz Muhammad Ali h, Nida Zahra, MuzamilHussain, Mohsin Ali Badshah, Ali TurabJafry.(2019). Applications of nanofluids in photovoltaic thermal systems: A review of recent advances, Physica A, 536, 122-513

8. Ahmed S. Abdelrazik, FA Al-Sulaimana,R. Saidurb, R. Ben Mansoura. (2018). A review on recent development for the design and packaging of hybrid photovoltaic/thermal (PV/T) solar systems, Renewable and Sustainable Energy Reviews 95, 110- 129.

9. Solar heat worldwide. International Energy Agency Solar Heating \& Cooling Programme.(2016). www.iea shc.org/data/sites/1/ publications/Solar-Heat-Worldwide-2015.pdf.
10. Y. Khanjari, F. Pourfayaz, A.B. Kasaeian. (2016) Numerical investigation on using of nanofluid in a water-cooled photovoltaic thermal system, Energy Conversion and Management, 122, 263-278

11. A. Makki, S. Omer, and H. Sabir. (2015). Advancements in hybrid photovoltaic systems for enhanced solar cell performance, Renew Sustain. Energy Rev, vol. 41, pp. 658-684

12. V. V Tyagi, S. C. Kaushik, and S. K. Tyagi. (2012). Advancement in solar photovoltaic/thermal (PV / T) hybrid collector technology, Renew. Sustain. Energy Rev, vol. 16, no. 3, pp. 1383-1398

13. Feng C, Zheng H, Wang R, Yu X, Su Y. (2015). A novel solar multifunctional PV/T/D system for green building roofs,Energy Convers Manage, 93:63-71

14. Singh S, Agrawal S, Avasthi DV. (2016). Design, modeling and performance analysis of dual-channel semitransparent photovoltaic thermal hybrid module in the cold environment, Energy Convers Manage, 114, 241-50

15. Wu Y-Y, Wu S-Y, Xiao L. (2015). Performance analysis of the photovoltaic-thermoelectric hybrid system with and without glass cover, Energy Convers Manage, 93, 151-9

16. Ibrahim A, Othman MY, Ruslan MH, Mat S, Sopian K. (2011)Recent advances in flat-plate photovoltaic/ thermal (PV/T) solar collectors, Renew Sustain Energy Rev, 15(1):352-65

17. Yoon J, Li LF, Semichaevsky AV, Ryu JH, Johnson HT, Nuzzo RG. (2011). Flexible concentrator photovoltaics based on micro-scale silicon solar cells embedded in luminescent waveguides, Nat Commun, 2, 1-8

18. Zafar Saida, Sahil Arorab, Evangelos Bellosc. (2018). A review on performance and environmental effects of conventional and nanofluid-based thermal photovoltaics, Renewable and Sustainable Energy Reviews, 94, 302-316

19. Bajestan EE, Moghadam MC, Daungthongsuk HNW, Wongwises S. (2016). Experimental and numerical investigation of nanofluids heat transfer characteristics for application in solar heat exchangers, Int J Heat Mass Transf, 92, 1041-52

20. Farideh Yazdanifarda, b, Mehran Amerib, Ehsan Ebrahimnia- Bajestanc. (2017). Performance of nanofluid-based photovoltaic/thermal systems: A review. Renewable and Sustainable Energy Reviews, 76 323-352

21. Sokhansefat T, Kasaeian AB, Kowsary F. (2014). Heat transfer enhancement in parabolic trough collector tube using Al2O3/synthetic oil nanofluid. Renew Sustain Energy Rev, 33, 636-44 
22. F.A. Sachit, M.A.M. Rosli, N. Tamaldin, S. Misha, A.L.Abdullah. (2018). Nanofluids Used in Photovoltaic Thermal (PV/T) Systems: a Review. International Journal of Engineering \& Technology, 7 3.20, 599611

23. Kasaeian A, Eshghi AT, Sameti M. (2015). A review on the applications of nanofluids in solar energy systems. Renew Sustain Energy, Rev, 43, 584-98

24. Verma SK, Tiwari AK. (2015). Progress of nanofluid application in solar collectors: a review. Energy Convers Manag, 100, 46-324

25. Hasanuzzaman $M$, Malek $A$, Islam M, Pandey A, Rahim N. (2016). Global advancement of cooling technologies for PV systems: a review. Sol Energy, 137, 25-45

26. Shukla A, Kant K, Sharma A, Biwole PH. (2017). Cooling methodologies of photovoltaic module for enhancing electrical efficiency: a review. Sol Energy Mater Sol Cells, 160:275-86.

27. Ali H.A. Al-Waelia, Miqdam T. Chaichanb, Hussein A. Kazema, K. Sopiana.(2019). Evaluation and analysis of nanofluid and surfactant impact on photovoltaic-thermal systems, Case Studies in Thermal Engineering, 13,100-392.

28. K. H. Solangi, S. N. Kazi, M. R. Luhur, A. Badarudin, A. Amiri, S. Rad, M. N. M. Zubir, G. Samira, K. $H$. Ten. (2015). A comprehensive review of thermo-physical properties and convective heat transfer to nanofluids', energy, 89, 86-1065

29. M. M. Sarafraz, F. Hormozi. (2015). Pool boiling heat transfer to dilute copper oxide aqueous nanofluids. International Journal of Thermal Sciences, 90, 224237

30. S. Manikandan and K. S. Rajan.(2016).Sand-propylene glycol-water nanofluids for improved solar energy collection. Energy, vol. 113, pp. 917-929

31. National Nanotechnology Initiative. (2019). Official website of the United States National Nanotechnology Initiative.n.d., January, https://www.nano.gov

32. Choi, S. U. S. (2009). Nanofluids: From vision to reality through research. Journal of Heat Transfer 131, 33106-33109

33. K. Khanafer and K. Vafai. (2018). A review on the applications of nanofluids in the solar energy field. Renewable energy, vol. 123, pp. 398-406

34. Asmaa Ahmed, Hasan Baig, Senthilarasu Sundaram, and Tapas K. Mallick. (2019). Use of Nanofluids in Solar P.V./Thermal Systems. International Journal of Photoenergy, Hindawi, https://doi. org/10.1155/2019/8039129

35. E. Bellos, Z. Said, and C. Tzivanidis. (2018). The use of nanofluids in solar concentrating technologies: a comprehensive review. Journal of Cleaner Production, vol. 196, pp. 84-99
36. I. M. Mahbubul. (2019). Preparation, Characterization, Properties, and Application of Nanofluid

37. I. M. Mahbubul, E. B. Elcioglu, R. Saidur, and M. A. Amalina. (2017). Optimization of ultrasonication period for better dispersion and stability of $\mathrm{TiO}_{2}$-water nanofluid,Ultrasonics Sonochemistry, vol. 37, pp. 360-367

38. Kumar, M. S, Vasu, V, \&Gopal, A. V. (2016). Thermal conductivity and rheological studies for $\mathrm{Cu}-\mathrm{Zn}$ hybrid nanofluids with various base fluids. Journal of the Taiwan Institute of Chemical Engineers, 66, 321-327

39. Bozorgan N, Shafahi M. (2015). Performance evaluation of nano-fluids in solar energy: A review of the recent literature. Micro and Nano Systems Letters, 35, 1-15

40. Hussain HA, Jawad Q, Sultan KF. (2015). Experimental analysis on the thermal efficiency of evacuated tube solar collectors by using nanofluids. International Journal of Sustainable and Green Energy, 4:19-28

41. Liu, J, Xu, C, Chen, L, Fang, X, \& Zhang, Z. (2017). Preparation and photo-thermal conversion performance of modified graphene/ionic liquid nanofluids with excellent dispersion stability. Solar EnergyMaterials and Solar Cells, 170, 219-232

42. Wisut Chamsa-ard, Sridevi Brundavanam, Chun Che Fung, Derek Fawcett and Gerrard Poinern. (2017). Nanofluid Types, Their Synthesis, Properties and Incorporation in Direct Solar Thermal Collectors: A Review. Journalnanomaterials, 7, 131; DOI:10.3390/ nano7060131

43. Chen, M.; He, Y.; Zhu, J.; Kim, D.R. (2016). Enhancement of photo-thermal conversion using gold nanofluids with different particle sizes. Energy Convers. Manag, 112, 21-30

44. Milanese $M$, Colangelo $G$, Cretì A, Lomascolo $M$, lacobazzi F, de Risi A. (2016). Optical absorption measurements of oxide nanoparticles for application as nanofluid indirect absorption solar power systems-Part II: $\mathrm{ZnO}, \mathrm{CeO}_{2}, \mathrm{Fe}_{2} \mathrm{O}_{3}$ nanoparticles behavior. Sol Energy Mater Sol Cells,147, 321-6

45. Milanese Marco, lacobazzi Fabrizio, Colangelo Gianpiero, de Risi Arturo. (2016). An investigation of layering phenomenon at the liquid-solid interface in $\mathrm{Cu}$ and $\mathrm{CuO}$ based nanofluids. Int $\mathrm{J}$ Heat Mass Transfer, 103, 564-71

46. V. Kumaresan and R. Velraj. (2012). Experimental investigation of the thermophysical properties of water-ethylene glycol mixture based CNT nanofluids, Thermochim,Acta, vol. 545, pp. 180-186

47. Su D, Jia Y, Huang X, Alva G, Tang Y, Fang G. (2016). Dynamic performance analysis of photovoltaic- thermal solar collector with dual channels for different fluids 04.095, 120:13-24. DOI: 10.1016/j. enconman 
48. Murshed, S.M.S.; Leong, K.C.; Yang, C. (2008). Thermophysical and electrokinetic properties of nanofluids: A critical review. Appl. ThermEng, 28, 2109-2125.

49. Sharma AK, Tiwari AK, Dixit AR. Rheological behavior of nanofluids: a review. (2016). Renewable Sustainable Energy Rev, 53:779-91

50. Li, Q,Yimin, X, Jian, W. (2006). Measurement of the viscosity of dilute magnetic fluids. Int. J.Thermophys, 27, 103-113

51. Hung, Y.H, Wen-Chieh, C. (2012). Chitosan for suspension performance and viscosity of MWCNTs. Int. J. Chem. Eng, 3, 347-353

52. Said Z, Sajid MH, Alim MA, Saidur R, Rahim NA. (2013). Experimental investigation of the thermophysical properties of $\mathrm{Al}_{2} \mathrm{O}_{3}$-nanofluid and its effect on a flat plate solar collector. IntCommun Heat Mass Transf, 48:99-107.

53. I. C. Nelson, D. Banerjee, and R. Ponnappan. (2009). Flow Loop Experiments Using PolyalphaolefinNanofluids. J. Thermophys, Heat Transf, vol. 23, no. 4, pp. 752-761

54. B. X. Wang, L. P. Zhou, X. F. Peng, X. Z. Du and Y. P. Yang. (2010). On the specific heat capacity of CuOnanofluid. Adv. Mech. Eng, vol. 2010

55. Wang, XQ \&Mujumdar, AS . (2008). A review on nanofluids: Part II Experiments and applications. Brazilian Journal of Chemical Engineering, 25(4), 631-348

56. Azmi WH, Sharma KV, Mamat R, Najafi G, Mohamad MS. (2016). The enhancement of effective thermal conductivity and effective dynamic viscosity of nanofluids e a review. Renewable Sustainable Energy Rev, 53:1046-58

57. Chitra SR, Sendhilnathan S. (2013). An innovative studies and analysis on thermal behavior in nanofluids. Int J SciEng Res, 4(5):284-90

58. Sridhara, V \&Satapathy, LN (2015). Effect of nanoparticles on thermal properties enhancement in different oils: A review. Critical Reviews in Solid State and Materials Sciences, 40(6), 399-424

59. S. Manikandan and K. S. Rajan. (2016). Sand-propylene glycol-water nanofluids for improved solar energy collection. Energy, vol. 113, pp. 917-929

60. Jing D, Hu Y, Liu M, Wei J, Guo L. (2015). Preparation of highly dispersed nanofluid and CFD study of its utilization in a concentrating $\mathrm{PV} / \mathrm{T}$ system, Sol Energy, 112:30-40

61. Ali H.A. Al-Waeli, K. Sopian, Miqdam T. Chaichan, Hussein A. Kazem, Husam Abdulrasool Hasan, Ali Najah Al-Shamani. (2017). An experimental investigation of $\mathrm{SiC}$ nanofluid as a base-fluid for a photovoltaic thermal PV/T system, Energy Conversion and Management, 142, 547-558
62. S.Hassani, R. A. Taylor, S. Mekhilef, and R. Saidur. (2016). A cascade nanofluid-based PV/T system with optimized optical and thermal properties. Energy, vol. 112, pp. 963-975

63. K. Rahbar, A. Riasi, H. Khatam Bolouri Sangjoeei, and N. Razmjoo. (2019). Heat recovery of nanofluid based concentrating photovoltaic thermal (CPV/T) collector with organic Rankine cycle. Energy Conversion and Management, vol. 179, pp. 373-396

64. An W, Wu J, Zhu T, Zhu Q. (2016). Experimental investigation of a concentrating $\mathrm{PV} / \mathrm{T}$ collector with $\mathrm{Cu}_{9} \mathrm{~S}_{5}$ nanofluid spectral splitting filter. Appl Energy, 184:197-206

65. Michael JJ, Iniyan S. (2015). Performance analysis of a copper sheet laminated photovoltaic thermal collector using copper oxide-water nanofluid. Solar Energy, 119:439-51

66. Rejeb, O., Sardarabadi, M., Menezo, C., Passandideh-Fard, M., Dhaou, M.H., Jemni, A. (2016). Numerical and model validation of uncovered nanofluid sheet and tube type photovoltaic thermal solar system. Energy Convers, Manage, 110, 367-377

67. Mittal T, Saroha S, Bhalla V, Khullar V, Tyagi H, Taylor RA, et al. (2013). Numerical study of solar photovoltaic/thermal (PV/T) hybrid collector using nanofluids. ASME 2013 4th International Conference on Micro/Nanoscale Heat and Mass Transfer: American Society of Mechanical Engineers, p. V001T02A7VT02A7

68. Saroha S, Mittal T, Modi PJ, Bhalla V, Khullar V, Tyagi $\mathrm{H}$, et al. (2015). Theoretical Analysis and Testing of Nanofluids-Based Solar Photovoltaic/Thermal Hybrid Collector. Journal of Heat Transfer, 137:091015

69. Hassani S, Taylor RA, Mekhilef S, Saidur R. (2016). A cascade nanofluid-based PV/T system with optimized optical and thermal properties. Energy, 112:963-75

70. M. Chandrasekar, S. Suresh, A.C. Bose. (2010). Experimental investigations and theoretical determination of thermal conductivity and viscosity of $\mathrm{Al}_{2} \mathrm{O}_{3} /$ water nanofluid, Exp,Therm Fluid Sci. 34 (2), 210-216

71. M. Chandrasekar, S. Suresh, T. Senthilkumar. (2013). Passive cooling of standalone flat PV module with cotton wick structures, Energy Convers, Manage, 71, 43-50

72. T.-K. Hong, H.-S. Yang, C. Choi. (2005). Study of the enhanced thermal conductivity of Fe nanofluids. J. Appl. Phys, 97, (6), 064311

73. Hashim A. Hussein, Ali H. Numan, and Ruaa A. (2017). Abdulrahman, Improving the Hybrid Photovoltaic/Thermal System Performance Using Water-Cooling Technique and $\mathrm{Zn}-\mathrm{H}_{2} \mathrm{O}$ Nanofluid.Hindawi International Journal of Photoenergy, Volume Article ID 6919054, 14 pages https://doi. org/10.1155/2017/6919054 
74. D. Lelea, D.G. Calinoiu, G. Trif-Tordai, A.E. Cioabla, I. Laza, F. Popescu. (2015). The hybrid nanofluid/ microchannel cooling solution for concentrated photovoltaic cells.in: AIP Conf. Proc, AIP, pp. 122-128

75. A. R. A. Hashim, A. Hussien, and A. H. Noman. Indoor investigation for improving the hybrid photovoltaic/thermal system performance using nanofluid (AL2O3-water). Engineering and Technology Journal, vol. 33, no. 4, pp. 889-901

76. M. Elmir, R. Mehdaoui, and A. Mojtabi. (2012). Numerical simulation of cooling a solar cell by forced convection in the presence of a nanofluid. Energy Procedia, vol. 18, pp. 594-603

77. M. Moradgholi, S. Mostafa Nowee, and A. Farzaneh. (2018). Experimental study of using Al2O3/methanol nanofluid in a two-phase closed thermosyphon (TPCT) array as a novel photovoltaic/thermal system. Sol. Energy, vol. 164, no. March, pp. 243-250

78. R. Gangadevi, B. K. Vinayagam, and S. Senthilraja. (2107). Experimental investigations of hybrid P.V./ Spiral flow thermal collector system performance using $\mathrm{Al}_{2} \mathrm{O}_{3}$ /water nanofluid. IOP Conf. Ser. Mater. Sci. Eng, vol. 197, p. 12041

79. Xu Z, Kleinstreuer C. (2014). Concentration photovoltaic-thermal energy co-generation system using nanofluids for cooling and heating. Energy Conversion and Management, 87:504-12

80. Xu Z, Kleinstreuer C. (2014). Computational analysis of nanofluid cooling of high concentration photovoltaic cells. Journal of Thermal Science and Engineering Applications, 6:031009

81. Tang LQ, Zhu QZ. (2014). Performance study of flowing-over $\mathrm{PV} / \mathrm{T}$ system with different working fluid. Applied Mechanics and Materials, Trans Tech Publ, p. 1173-6.

82. Hussien HA, Noman AH, Abdulmunem AR. (2015). Indoor investigation for improving the hybrid photovoltaic /thermal system performance using nanofluid $\left(\mathrm{Al}_{2} \mathrm{O}_{3}\right.$-water). Eng Tech J, 33(4):889-901.

83. A. N. Al-Shamani, M. A. Alghoul, A. M. Elbreki, A. A. Ammar, A. M. Abed, and K. Sopian (2018). Mathematical and experimental evaluation of thermal and electrical efficiency of PV/T collector using different water-based nanofluids. Energy, vol. 145, pp. 770792

84. Mahian, O.; Kianifar, A.; Kalogirou, S.A.; Pop, I.; Wongwises, S. (2013). A review of the applications of nanofluidsin solar energy. Int. J. Heat Mass Transf,57, 582-594.

85. A. N. Al-Shamani, K. Sopian, S. Mat, H. A. Hasan, A. M. Abed, and M. H. Ruslan. (2016). Experimental studies of rectangular tube absorber photovoltaic thermal collector with various types of nanofluids under the tropical climate conditions. Energy Conversion and Management, vol. 124, pp. 528-542
86. Sardarabadi M, Passandideh-Fard M, Heris SZ. (2014). Experimental investigation of the effects of silica/water nanofluid on PV/T (photovoltaic thermal units). Energy, 66:264-72

87. A. Noghrehabadi, E. Hajidavalloo, M. Moravej. (2016). An experimental investigation on the performance of asymmetric conical solar collectors using $\mathrm{SiO} 2 /$ water nanofluid, Transp. Phenom. Nano-Micro Scales, 5 (1) 23-29

88. M. Ghadiri, M. Sardarabadi, M. Pasandideh-Fard, and A. J. Moghadam. (2015). Experimental investigation of a PVT system performance using nanoferrofluids. Energy Conversion and Management, vol. 103, pp. 468-476

89. Jin J, Jing D. (2017). A novel liquid optical filter based on magnetic electrolyte nanofluids for hybrid photovoltaic/thermal solar collector application. Sol Energy,155:51-61,https://doi.org/10.1016/j.solener. 2017.06.030

90. F. Yazdanifard, E. Ebrahimnia-Bajestan, M. Ameri. (2107). Performance of a parabolic trough concentrating photovoltaic/thermal system: effects offlow regime, design parameters, and using nanofluids, Energy Convers. Manage, 148, 1265-1277

91. M. Sardarabadi, M. Passandideh-Fard. (2016). Experimental and numerical study of metal-oxides/ water nanofluids as coolant in photovoltaic thermal systems (PVT), Sol. Energy Mater. Sol. Cells 157, 533-542

92. D. Das, P. Kalita. (2017). Performance improvement of a novel flat plate photovoltaic thermal (PV/T) system using copper oxide nanoparticle-water as coolant, in: International Conference on Nano for Energy and Water, Springer, pp. 97-104

93. E. Bellos and C. Tzivanidis. (2019). Investigation of a nanofluid based concentrating thermal photovoltaic with a parabolic reflector.Energy Conversion and Management, vol. 180, pp. 171-182,

94. M. Hosseinzadeh, A. Salari, M. Sardarabadi, and M. Passandideh-Fard. (2018). Optimization and parametric analysis of a nanofluid based photovoltaic thermal system: 3D numerical model with experimental validation, Energy Convers. Manag, vol. 160, no. October 2017, pp. 93-108

95. Yun CUI, Qunzhi ZHU. (2012). Study of Photovoltaic/Thermal Systems with MgOWaterNanofluids Flowing over Silicon Solar Cells, 978-1-4577-05472/12/\$31.00 C2012 IEEE

96. S. Soltani, A. Kasaeian, H. Sarrafha, D. Wen. (2017). An experimental investigation of a hybrid photovoltaic/thermoelectric system with nanofluid application. Sol. Energy, 155,1033-1043

97. Joo Hee Lee, Seong Geon Hwang and Gwi Hyun Lee. (2019). Efficiency Improvement of a Photovoltaic Thermal (PVT) System Using Nanofluids. Energies, 12, 3063; DOI:10.3390/en12163063. 
98. Yazdanifard, F.; Ameri, M.; Ebrahimnia-Bajestan, E. (2017). Performance of nanofluid-based photovoltaic/thermal systems: A review. Renew. Sustain. Energy Rev, 76, 323-352

99. M. ImtiazHussain, Jin-Hee Kim and Jun-Tae Kim. (2019). Nanofluid-Powered Dual-Fluid Photovoltaic/Thermal (PV/T) System: Comparative Numerical Study, Energies, 12, 775, DOI:10.3390/en12050775

100. M. Sardarabadi, M. Hosseinzadeh, A. Kazemian, and M. Passandideh-Fard. (2017). Experimental investigation of the effects of using metal-oxides/ water nanofluids on a photovoltaic thermal system (PVT) from energy and exergy viewpoints. Energy, vol. 138, pp. 682-695
101. Saber Ragab Abdallah, Hind Saidani-Scott, Osama Ezzat Abdellatif. (2019). Performance analysis for hybrid PV/T system using low concentration MWCNT (water-based) nanofluid, Solar Energy $181,108-115$.

102. R. Nasrin, NA. Rahim, H. Fayaz, M. Hasanuzzaman, Water/MWCNT nanofluid based cooling system of PVT. (2018). Experimental and numerical research Renewable Energy, 121, 286-300.

103. Fayaz, H., Nasrin, R., Rahim, N.A., Hasanuzzaman, M. (2018). Energy and exergy analysis of the PVT system: effect of Nanofluid flow rate. Sol. Energy, 169, 217-230. 